\title{
NILAI-NILAI KERUKUNAN VIHARA DARMA RHAMSI DI JAWA BARAT
}

\author{
Herlina Nurani \\ Mahasiswa Religious Study Program Magister UIN Sunan Gunung Djati Bandung \\ Jl. A.H. Nasution 105 Cibiru, Bandung 40614, Indonesia. \\ E-mail: Nuranienci@gmail.com
}

\begin{abstract}
A conviction, however, the shape is not born from empty space, including a religious sect. He comes from a special variety of life experiences that a person experiences appropriate yan $g$ embraces these beliefs. In practice a cult require means to be recognized. This research seeks to understand the characteristics of a sect that has a very unique, with different religious backgrounds but to sustain an existence of their religion, they establish sect. By using a kulitatif method in Darma Ramsi monastery Cibadak an object of study, researchers sought explores the other side of this sect. The results of this study concluded that the concept of many according to Ramsi Vihara Dharma is by giving what is needed other people, namely in the form of staple food, because in a way it is similar to a living person, when the activity was undertaken gods will be happy and radiated to the monastery pilgrims themselves.
\end{abstract}

Keywords:

Sect;exsistance;give

\begin{abstract}
Abstrak
Suatu keyakinan, bagaimanapun bentuknya tidak lahir dari ruang kosong, termasuk sekte suatu agama. Ia hadir dari berbagai pengalaman hidup yang istimewa sesuai yang dialami seseorang yang memeluk keyakinan tersebut. Dalam prakteknya sebuah sekte membutuhkan sarana untuk dapat diakui. Penelitian ini berupaya untuk memahami suatu sekte yang memiliki ciri yang sangat unik, dengan latar belakang agama yang berbeda namun untuk mempertahankan sebuah eksistensi dari masing-masing agamanya, mereka mendidrikan sebuah sekte baru. Dengan menggunakan metode kualitatif di vihara Darma Ramsi Cibadak sebagai objek studi, Peneliti berupaya mengungkap sisi lain dari sekte ini. Hasil studi ini menyimpulkan bahwa untuk mewujudkan kerukunan antar umat yang berbeda agama konsep berbagi menurut Vihara Darma Ramsi adalah dengan cara memberi apa yang di butuhkan orang lain, yaitu berupa makanan pokok, sebab dengan cara itu sama halnya dengan menyambung hidup seseorang, saat kegiatan itu di lakukan dewa akan bahagia dan terpancar kepada diri jamaat vih ara.
\end{abstract}

Kata Kunci:

Sekte;eksistensi;berbagi.

\section{A. PENDAHULUAN}

Sebagaimana yang di ungkapan C.J. Blekeer dalam bukunya pertemuan agamaagama dunia, ia mengatakan bahwa apapun yang terjadi rangka dasar sifat keagamaan penduduk pasti akan dapat mempertahankan diri. $^{1}$ Seperti juga yang dilakukan oleh agama hindu, budha, konfusianisme yang datang ke indonesia, untuk mempertahankan eksistensi agama mereka amsing-masing, mereka bersatu dalam satu visi dan misi hingga menjadi sebuah sekte, nama sekte tersebut adalah

${ }^{1}$ C.j. Blekeer, Pertemuan agama-agama di dunia, pustaka dian pratama, jogjakarta : 20014.
Tridarma. Nama Tridarma diambil dari kata Tri berarti tiga dan darma berati kebenaran, secara jelasnya Tri darma merupakan tiga kebenaran dari agama hindu, budha mahayana, dan konfusius. Pergerakan dimulainya pada awal tahun 1920-an yang dipelopori oleh kwee Tek Hoay yang mana kemudian Kwee Tek hoay diangkat menjadi Bapak Tridharma di Indonesia. Pada awalnya perkembangan Tridharma hingga tahun 1960an, Tridharma dikenal dengan nama Sam Kauw. Sam Kauw Hwee (tiga agama) didirikan oleh Kwee Tok Hoay bersama kawannya pada tahun 1934 bersamaan dengan terbitnya sebuah majalah bulanan tiga agama 
yang bernama Sam Kauw Gwat Po. ${ }^{2}$ Dalam nomor tiga Sam Kauw Gwat Po. Kwee menyatakan bahwa mereka tidak bermaksud menyatukan ketiga agama menjadi satu tetapi tetap mempertahankan identitas ketiga agama tersebut. Ia mengakui bahwa untuk mayoritas orang China di Indonesia tiga agama ini telah tercampur dan nampaknya telah bersatu. ${ }^{3}$

Sam Kauw Hwee yang telah dirubah menjadi Gabungan Sam Kauw Indonesia (GKSI) berubah menjadi Gabungan Tridharma Indonesia (GTI) yang resmi didirikan pada tanggal 20 Februari 1952 pukul 12.00 WIB echtsperson/Legal body berdasarkan penetapan Menteri dan berbentuk badan hukum/12 pada tanggal 9 April 1953 terbentuk Kehakiman R.I No. JA. 5/31/13 dan termuat dalam tambahan berita Negara RI. No. 33 tanggal 24 April 1953 urutan No. 3. dan GTI juga terdaftar pada Departemen Agama RI. hasil yang sudah di rapatkan Berdasarkan hasilnya rapat tersebut anggota Gabungan Tridharma Indonesia yang berlangsung pada tanggal 16-18 April 1976 maka ditetapkan 31 Juli sebagai hari lahir Bapak Kwee Tek Hoay (Bapak Tridharma Indonesia) diperingati sebagai hari Tridharma/hari kebangkitan Tridharma Indonesia.

Kwee Tek Hoay memiliki murid yang datang ke Bandung untuk melanjutkan tujuannya yaitu membentuk Tempat Ibadat Tri Dharma karena klenteng-klenteng di Jawa Timur terancam punah sebagai akibat dari persepsi yang kurang lengkap dari Penguasa Perang Daerah terhadap klenteng yang dianggapnya sebagai Lembaga Kecinaan yang non agama pasca G30S/PKI tahun 1965. Padahal tridarma merupakan suatu kesatuan ajaran budha, hindu, konfusionisme. Dan murid dari Kwee Tek Hoay yang merupakan pendatang dari negara tiongkok dan menjadi pengurus di klenteng besar di tiongkok ini yang mendirikan Vihara

\footnotetext{
${ }^{2}$ Leo Suryadinata, Mencari Identitas Nasional: dari Tjoe Bousan sampai Yap Thiam Hien, (Jakarta: LP3ES, 1990), h. 71

3 Rochmayanti, Skripsi: Upacara Puja Bhakti dalam Ajaran tridharma Bagi Masyarakat Cina, (Jakarta, 2002), h. 11
}

di Bandung dengan nama Vihara Darma Ramsi.

Yang menarik dari Vihara tersebut adalah pemahaman tentang pentingnya nilai kemanusiaan dengan cara menyayangi dengan bentuk berbagi, mereka meyakini bahwa dengan berbagi, mereka sudah memberikan kelangsungan hidup untuk orang lain, dan dewa atau leluruh menyukai orang yang terus memberikan makanan yang dia punya untuk orang lain.

\section{B. HASIL DAN PEMBAHASAN \\ 1. Asal Usul Vihara Darma Ramsi}

Pada tahun 1954 Amingse Samo Amoyse datang ke Indonesia dan mendirikan sebuah Vihara yang diberi nama Vihara Dharma ramsi yang bertempat di Bandung jl. Cibadak, Gang Ibu Aisyah, No.18-19. Vihara ini sempat beberapa kali mengalami renovasi, awalnya pada dinding-dinding kebaktian terdapat gambar-gambar para tokoh rohaniawan dan dewa-dewa dengan tujuan agar selalu mengingat roh luluhur atau nenek moyang mereka. selain itu tempat ibadah juga identik dengan asap dupa, maka berpengaruh tehadap gambar hingga menjadi kusam dan menguning, oleh karena itu Vihara inipun mengalami renopasi sebanyak 3 kali. Hingga bentuk dan juga luas ruangannya menjadi lebih baik.

Bapak Subuana atau akrab di panggil Pobuan, beliau merupakan ketua Vihara darma Ramsi, lahir di bandung pada tahun 43, merupakan anak pertama yang terlahir dari keluarga yang beragama kristen, bahkan salah satu adiknya yang menjadi biarawati. Dan hanya beliau yang beragama budha, beliau mengungkapankan alasan mengapa memeluk agama budha, karena di agama budhalah seorang pobuan ini mendapat ketentraman hati. Hingga pada tahun 1981 beliau diangkat menjadi kepala pengurus yayasan vihara dharma ramsi.

\section{Metodologi yang Digunakan}

Berdasarkan fokus dan tujuan penelitian, maka penelitian bertujuan untuk mendapatkan gambaran lengkap mengenai bagaimana 
konsep sosial Vihara Darma Ramsi bentuk pada masyarakat sekitar, adapun metode yang digunakan adalah pendekatan Kualitatif.

Seperti yang dikutip Sukardi, metode penelitian kualitatif adalah metode penelitian yang berusaha menggambarkan dan menginterpretasikan objek penelitian sesuai dengan apa yang teradi di lapangan. ${ }^{5}$

Sugiyono dalam bukunya Metode Penelitian kombinasi mengatakan bahwa metode penelitian kualitatif sering disebut metode penelitian naturalistik, karena penelitiannya dilakukan pada kondisi yang alamiah (Natural Setting). ${ }^{6}$ Dikatakan naturalistik karena situasi di lapangan penelitian bersifat natural atau wajar, sebagaimana adanya, tanpa dimanipulasi, juga tidak diatur dengan eksperimen atau tes. Penelitian kualitatif berakar pada latar alamiah sebagai keutuhan, mengandalkan manusia sebagai alat penelitian, memanfaatkan metode kualitatif, dan mengadakan analisis data secara induktif. Penelitian kualitatif juga bersifat deskriptif, lebih mementingkan proses daripada hasil, membatasi kajian dengan fokus memiliki seperangkat kriteria untuk menjamin keabsahan data, rancangan penelitiannya bersifat sementara, dan hasil penelitiannya disepakati oleh kedua pihak. $^{7}$

Metode penelitian kualitatif juga berlandaskan pada filsafat post positivisme yang memandang realitas social sebagai sesatu yang holistic, komplek, dinamis, penuh makna dan hubungan gejala bersifat interaktif. Penelitian di lakukan pada objek yang alamiah.

Objek alamiah adalah objek yang berkembang apa adanya, tidak di manipulusi oleh peneliti dan kehadiran peneliti tidak mempengaruhi dinamika pada objek tersebut. Untuk mejadi istrumen maka peneliti harus

4 Noeng Muhadjir, Metodologi Keilmuan: Paradigma Kualitatif, Kuantitatif, dan Mixed, (Yogyakarta: Rake Sarasin, 2007), 136.

Sukardi, Metode Penelitian Pendidikan: Kompetensi dan Prakteknya, (Jakarta: Bumi Aksara, 2005), hlm. 157.

${ }^{6}$ Prof. Dr. Sugiyono, Metode Penelitian Kombinasi (Mixed Methods), (Bandung: ALFABETA, 2015), 13.

${ }^{7}$ Dr. Lexy J. Moleonng, M.A, Metodologi Penelitian Kualitatif, (Banndung, Rosdakarya, 1994), 4-5. memiliki bekal teori dan wawasan yang luas, sehigga mampu bertanya, menganalisis, memotret, dan mengkostruksi situasi social yang diteliti menjadi lebih jelas dan bermakna. Analisis data yang di pakai bersifat induktif berdasarkan fakta-fakta yang ditemukan di lapangan dan kemudian dikonstruksikan menjadi hipotesis atau teori. Metode kualitatif digunakan untuk mendapatkan data yang mendalam,data yang sebenarnya,data yang merupakan suatu nilai di balik data yang tampak. Oleh karena itu dalam penelitian kualitatif tidak menekankan pada generalisasi tetapi lebih menekankan pada makna. ${ }^{8}$

Pendekatan kualitatif dipilih, karena pendekatan kualitatif mampu mendeskripsikan sekaligus memahami makna yang mendasari tingkah laku partisipan, mendiskripsikan latar dan interaksi yang kompleks, eksplorasi untuk mengidentifikasi tipe-tipe informasi, dan mendeskripsikan fenomena.

Berdasarkan hal tersebut, maka dalam penelitian ini peneliti ikut berpartisipasi lama dengan tinggal kurang lebih 10 tahun dilapangan,mencatat dengan hati-hati apa yang terjadi, melakukan analisis reflektif terhadap berbagai dokumen yang di temukan di lapangan dan membuat laporan penelitian secara mendetail.

\section{Mengenal Simbol Bentuk dan Bangunan Vihara}

Penulis menemukan landasan bentuk bangunan vihara tersebut mempunyai ciri khas sunda, dengan bentuk atap seperti pendopo namun tidak terlepas dari keyakinan khusus seperti klenteng untuk agama konghucu yang terdapat patung naga, dan memiliki warna merah, simbol warna merah merupakan keberanian, bahwa mereka harus berani dalam menyampaikan kebenaran, seperti gerbang atau pagar yang diberi warna merah, juga tulisan yang berwarna kuning, melambangkan, kekayaan yang melimpah.

\footnotetext{
${ }^{8}$ Sugiyono, Metode Penelitian Kombinasi (Mixed Methods), 13.

9 Sanapiah Faisal, Penelitian Kualitatif: DasarDasar dan Aplikasi, (Malang: YA3, 1990),. 22
} 


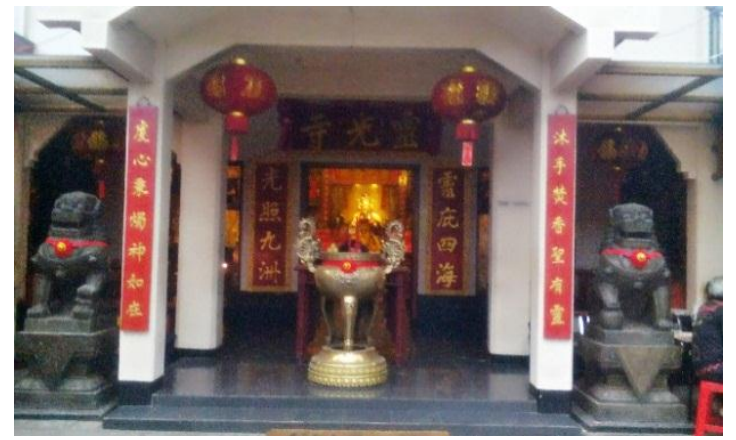

Gambar 1. Pintu masuk Vihara.

Seperti yang di ungkapkan pobuan " karena warna kuning sama dengan emas, yang mempunyai nilai yang tinggi dan sangat mahal, dan hanya bisa di dapatkan oleh orangorang yang mampu, juga melambangkan keagungan untuk sang Budha itu sendiri yang akan terus di kenang karena sebagai sosok yang memberikan jalan kebenaran untuk umatnya lewat pencariannya, dan kejayaan, bukan kejayaan di dunia tetapi kejayaaan setelah meninggal," 10 begitupun dunia ini tidak ada yang abadi seperti yang di jumpai oleh sang budha ketika masa mengembara, yang bertemu dengan orang yang tua renta, orang yang sakit,orang meninggal.dan yang meneguhkan hati sang budha ia bertemu dengan orang suci, yang memberi arahan kepada sang budha atas pertanyaan untuk mencari kebenaran. ${ }^{11}$ Selain itu simbol dinding luar berwarna puth, yang mempunyai arti bahwa putih melambangkan kesucian, di mana tempat beribadah itu harus suci dari segi apapun, termasuk orang yang beribadah ke vihara hatinya harus suci, dan berniat untuk ibadah menghadap Dewa dan Budha. Simbol dari halaman tidak di ceritakan secara khusus, namun terdapat tempat duduk untuk umat yang beristirahat, dan tempat penjaga. Untuk bertanya, dan meminta ijin.

\section{Makna Simbol Ritual Ibadah}

Pertama membutuhkan gong, yang fungsinya untuk memanggil dewa-dewa, dan mem-

\footnotetext{
${ }^{10}$ Wawancara dengan pobuan, pada hari Minggu, 22, September, pukul : 15:00 WIB.

${ }^{11}$ Huston Smith, Agama-Agama Manusia.
}

beri tahukan bahwa mereka yang di vihara sedang mengadakan ritual untuk para dewa.

Kedua dufa, yaitu alat untuk ritual penyembahan, sekaligus pengampunan dosa kepada sang Budha, asap dufa tersebut dipercaya akan sampai ke langit dan sampai kepada dewa.

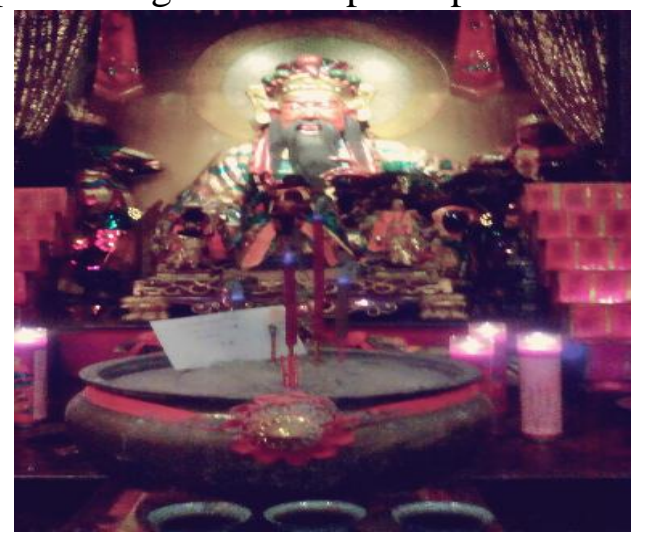

Gambar 2. merupakan gambar dupa untuk penymbahan kepada Dewa, dan patung dewa perang Konghucu, yang di yakini sebagai dewa yang selalu menyelamatkan umatnya.

Ketiga, yaitu lilin, manfaat dari lilin sendiri adalah sebagai penerang, lilin memiliki nilai filosofis tersendiri yaitu satu lilin di percayai mampu menerangi seluluh dunia, meskipun lilin tersebut selalu di lupakan. Padahal jasa lilin sangat besar, dia rela habis untuk menerangi dunia yang gelap. Seperti yang di ungkapkan pobuan "lilin merupakan penerang yang sangat berarti bagi malam yang gelap artinya dunia butuh penerangan dan bisa terangi dengan lilin. Begitupun dengan kehidupan, lilin akan menerangi kehidupan manusia, jadi bukan hiasan namun mempunyai makna tertentu. ${ }^{12}$ Dan lilin ini memiliki fungsi khusus di vihara darma ramsi. Setiap tahun baru lilin tersebut dijadikan pajangan di Vihara dengan harapan di tahun baru, dan mengingat para penyumbang kepada vihara. karena orang- orang yang menyumbang atau donatur akan selalu di do'akan oleh orang yang berkunjung ke vihara, karena namanama donatur tersebut di cantumkan namanya di lilin yang berukuran cukup besar dengan panjang 1 meter, lebar kurang lebih $15 \mathrm{~cm}$. Ukuran panjangnya lilin akan di sesuaikan dengan banyaknya jumlah dana yang di

\footnotetext{
${ }^{12}$ Wawancara dengan pobuan, 22, September, pukul : 16:00 WIB.
} 
sumbangkan oleh donatur, jika yang banyak dana nya banyak maka lilin nya akan panjang, begitupun sebaliknya. Upaya Mewujudkan Kerukunan Umat Beragama Pada Masyarakat Setempat

\section{Kerukunan Hidup Antar Umat Beragama}

Pengertian kerukunan hidup antar umat beragama adalah terbinanya kesimbangan anatara hak dengan kewajiban dari setiap umat beragama. Keseimbangan anatara hak dan kewajiban itu adalah sungguh-sungguh dari setiap penganut agama untuk mengamalkan seluruh ajaran agamanya sehingga ia menjadi agamawan parpurna namun pada saat yang sama pengalaman ajaran agamanya tidak bersinggungan dengan kepentingan orang lain yang juga dimiliki hak untuk mengamalkan ajaran agamanya. ${ }^{13}$

Dalam menciptakan hidup bersama secara harmonis, di kalangan umat yang berbeda agama baik bersekala internasional, regional maupun dalam skala nasional, selalu terjadi dua bentuk sikap.

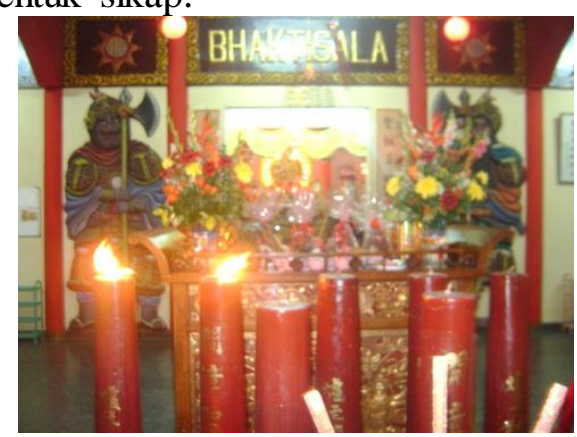

Gambar 3 merupakan bentuk dan ukuran lilin yang masing-masing di beri nama penyumbang dana pada Vihara.

Pertama, saling menghargai dan menghargai dan menghormati itu berjalan secara 'tidak sadar'. Artinya seseorang menghormati orang yang beragama lain itu hanya kepentingan politik, misalnya karena sama sama mendalami dunia yang satu manusia tidak pantas jika saling membunuh, saling menindas, saling mengusir atau karena sama sama satu bangsa dan negara sepantasnnya umat beragama saling rukun demi cita cita

\footnotetext{
${ }^{13}$ Said Agil Husin Al Munawar, Fikih Hubungan Antar Agama, Ciputat Press, Ciputat, 2005, hlm. 54
}

bersama. Kedua, penghormatan terhadap orang yang menganut agama lain itu muncul bukan hanya kepentingan politik tetapi lebih dari itu adanya kesadaran bahwa agamaagama yang dianut manusia di bumi ini memliki titik temu yang sangat mendasar.

Begitupun yang dilakukan oleh Jamaat Vihara Darma Ramsi yang meyakini bahwa ada yang penting di dunia ini yang menyatukan mereka dengan dewa yaitu dengan kasih sayang yang mereka berikan terhadap orang lain, dan yang menjadi istimewa mereka bukan hanya menerapkan konsep kasih sayang untuk sesama jemaat, namun kepada orang di luar jamaat pula.

Implikasi tersebut merujuk kepada kesatuan konsep hindu, budha, konfusius. Di hindu dalam dalam rangka mendukung terwujudnya kerukunan dan perdamaian dalam kehidupan bernegara kesatuan harus dilandasi etik dan moral ajaran Veda yang diaktualisasikan dalam sikap menyadari dirinya sebagai sahabat dari sesama umat manusia, baik intern umat Hindu, antar SARA, maupun dengan pemerintah. Mereka juga sebagai teman dari semua ciptaan Tuhan, karena berasal dari pencipta yang sama serta diisi dan digerakkan oleh sumber hidup yang sama.

Hal ini didasari oleh sloka Veda, antara lain dalam Svetasvatara Upanisad, Yajur Veda dan Isa Upanisad sebagai berikut

"Mitrasya ma caksusa sarvani bhutani samiksantam,

mitrasyaham caksusa sarvani bhutani samiksa,

mitrasya caksusa samiksa mahe "Y.V.XXXVI.18

Artinya: :mudah-mudahan semua mahluk melihat kami dengan penglihatan mata seorang sahabat. Semoga kami semua memandang mahluk sebagai seorang sahabat.

Semoga kami saling memandang dengan penuh persahabatan.

Kedua, senantiasa berupaya melakukan Dharma Agama melalui pengamalan ajaran agamanya secara benar dan utuh tanpa kepentingan yang bersifat eksklusif.a. Setiap 
umat Hindu hendaknya meyakini dan menghayati kebenaran ajaran Sradha dan mengamalkannya secara benar dan nyata dalam kehidupan sehari - hari. Pengamalan Sradha ini ditentukan didalam Atharva Veda XII.1.1 yang berbunyi :

$\begin{array}{llrr}\text { "Satyam brhad } & \text { rtam } & \text { ugram } \\ \text { diksa } & \text { tapo } & \text { brahma } & \text { yajna }\end{array}$
prthivim dharayanti “

Artinya: :kenyataanya berdirinya dunia ini disangga oleh Satyam ( kebenaran Tuhan ), Rtam ( hukum-Nya yang abadi ), Diksa ( penyucian diri ), Tapa ( pengendalian diri ), Brahma ( doa pujaan ) dan Yajna ( persembahan suci ).

Begitupun implikasinya mereka tunjukan dengan konsep menyayangi sesama manusia jamaat Dharma Rhamsi menunjukannya dengan cara berbagi, yaitu berbagi dalam bentuk makanan pokok, seperti sandang dan pangan. Contohnya beras, susu, telor, dan makanan pokok lainnya. Sebab mereka percaya semakin mereka memberi, maka dewa akan senang, dan akan mengetuk hati banyak donatur untuk datang ke Vihara untuk menyumbangkan hartanya. Kegiatan berbagi ini dilakukan setiap satu bulan 2 kali, vihara ini menerapkan konsep toleransi, dimana yang mendapatkan pemberian tersebut bukan hanya jemaat Vihara, namun melibatkan seluruh wagra Cibadak khususnya jl. Gang Aisyah No. 15. Proses pelaksanaanya ketua Vihara yaitu pobuan mengumumkan kepada semua warga Cibadak untuk berkumpul di depan Vihara, dan dibagikanlah makanan pokok tersebut.

Saat penulis menanyakan apa yang para jamaat rasakan setelah kegiatan tersebut, penulis mendapatkan jawaban bahwa mereka mendapatkan ketenangan dalam hati, mereka gambarkan wajah dewa yang tersenyum dan memancar kepada diri mereka yang juga merasakan bahagia.

Kegiatan membagikan makanan pokok ini ada yang menarik saat di laksanakan pada bulan mei, sebab bulan mei merupkan bulan yang istimewa, leluhur atau tokoh pendiri Vihara yaitu Amoise Samo Amingse lahir di bulan tersebut, oleh karena itu acara pembagian makanan pun dilakukan dengan berbeda seperti bulan biasanya. Bulan mei tepatnya tanggal 7, jemaat Vihara mengadakan do'a dan memukul gong, agar leluhur datang menyaksikan.

Dan yang datang bukan hanya jamaat vihara, namun orang yang bergama Islam pun menyaksikan ritual tersebut, mereka mengatakan tidak jarang warga yang beragama islam sering mengunjungi Vihara, jika lapar bahkan sekedar untuk minum dan jemaat Vihara pasti memberikan.

Pobuan juga menggambarkan bahwa ajaran hindu Dalam kitab Thay Hak, Da Xue IX:1 dinyatakan, bahwa Untuk mengatur Negara harus lebih dahulu membereskan rumah tangga. Jika tidak dapat mendidik keluarga sendiri tetapi dapat mendidik orang lain, itu hal yang tidak akan terjadi. Maka seorang Kuncu, Junzi (Insan Kamil) biar tidak keluar rumah, dapat menyempurnakan pendidikan di negaranya. Dengan berbakti kepada ayah bunda, dia turut mengabdi kepada Raja atau Pemimpin. Dengan sikap kita yang rendah hati, dia turut mengabdi kepada atasannya dan dengan bersikap kasih sayang, dia turut mengatur masyarakatnya.

Lebih jauh dalam kitab Thay Hak, Da Xue IX:3 \& 5, dinyatakan, bahwa Jika semua keluarga saling menyayangi niscaya seluruh $\mathrm{Ne}$ gara akan di dalam Cinta Kasih. Jika semua di dalam keluarga saling mengalah pastilah seluruh Negara ini akan di dalam suasana saling mengalah. beda dengan apabila orang tamak dan curang niscaya seluruh Negara akan terjerumus ke dalam kekalutan. Maka teraturnya Negara itu sesungguhnya berpangkal pada keberesan dalam rumah tangga.

Dalam budha toleransi diajarkan sebagai berikut:

Menurut pandangan agama Buddha, agama mana pun yang mengajarkan tiga yaitu kebijaksanaan, mensucikan diri, dan menyayangi ialah agama yang benar dan dapat membuat pengikutnya menjadi suci batinnya. Dengan demikianlah, agama Buddha mengakui adanya kebenaran dalam ajaran agama lain. ${ }^{14}$

\footnotetext{
${ }^{14}$ Wawancara dengan Pobuan
} 
Begitupun dalam Budha dijelaskan dalam kitab Bhagavad Gita 1V.II : Ye yatha mam prapadyante tams thathaiva bhajamy aham mama vartmanuvartante manusyah partha sarvasah.

Artinya :

Bagaimana pun perjalanan manusia mendekati-Ku, Aku terima, wahai Arjuna. Manusia mengikuti jalan-Ku pada segala jalan. ${ }^{15}$ Ajaran tersebut juga diaplikasikan dalam kehidupan sehari-hari oleh jamaat Vihara, dengan tujuan hidup rukun dan damai, maka komunikasi yang baik haruslah terjalin walaupun terhadap masyarakat yang berbeda agama dengan mereka.

\section{SIMPULAN}

Berdasarkan paparan di atas dapat disimpulkan beberapa point terpenting sebgai berikut: pertama, aliran darma ramsi sama dengan aliran tridarma, yaitu gabungan dari tiga kepercayaan agama yaitu budha,tao, dan konfhusionisme. Kedua, Kwee Tek Hoay pendiri aliran Tridarma adalah guru dari Amingse Samo Amoise pendiri Vihara Darma Ramsi. Ketiga, bahwa untuk menarik perhatian dan kasih sayang orang maka kita harus memberikan kasih sayang terlebih dahulu kepada orang lain. Karena dengan menyayanilah kita akan bersatu, dan bentuk kasih sayangnya mereka tunjukan dengan cara memberi makanan pokok yang selalu di berikan setiap satu bulan sekali kepada jemaat juga kepada warga sekitar vihara.

\section{DAFTAR PUSTAKA}

Blekeer, C.J, Pertemuan Agama-Agama di dunia, Pustaka Dian Pratama, Jogjakarta : 2014.

Faisal, Sanapiah, Penelitian Kualitatif: DasarDasar dan Aplikasi, Malang: YA3, 1990.

Moleong, Lexy J, Metodologi Penelitian Kualitatif, Banndung, Rosdakarya, 1994, 4-5.
Muhadjir, Noeng, Metodologi Keilmuan: Paradigma Kualitatif, Kuantitatif, dan Mixed, Yogyakarta: Rake Sarasin, 2007.

Rochmayanti, Skripsi: Upacara Puja Bhakti dalam Ajaran tridharma Bagi Masyarakat Cina, Jakarta, 2002.

Sugiyono, Metode Penelitian Kombinasi (Mixed Methods) Bandung: ALFABETA, 2015.

Sukardi, Metode Penelitian Pendidikan: Kompetensi dan Prakteknya, Jakarta: Bumi Aksara, 2005.

Suryadinata, Leo, Mencari Identitas Nasional: Dari Tjoe Bousan sampai Yap Thiam Hien, Jakarta: LP3ES, 1990.

Wawancara dengan pobuan, pada hari Minggu, 22, September, pukul : 15:00

\section{Internet:}

Wanderer, Solidarity, "Toleransi dalam Agama Buddha", 2010, diakses tanggal 23 Februari 2016, http://www.kompasiana.com/mr_ded/tole ransi-dalam-agama buddha_54ff6eefa33311804c510162

\footnotetext{
${ }^{15}$ http://www.kompasiana.com/mr_ded/toleransi-dalamagama-buddha_54ff6eefa33311804c510162
} 